PERSPECTIVA TEOLÓGICA ADERE A UMA LICENÇA CREATIVE COMMONS ATRIBUIÇÃO 4.0 INTERNACIONAL - (CC BY 4.0 )

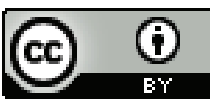

DOI: $10.20911 / 21768757 v 53 n 3 p 701 / 2021$

\title{
SANTA TERESA DE ÁVILA: 50 ANOS DOUTORA DA IGREJA
}

\author{
Saint Teresa of Avila: 50 Years Doctor of the Church
}

Lúcia Pedrosa-Pádua *

RESUMO: O presente artigo tem como objeto a declaração de Santa Teresa de Ávila como Doutora da Igreja, em 1970. Aprofunda alguns significados deste acontecimento para a teologia e, especialmente, para a relação entre este saber e as mulheres. Inicia apresentando a figura de Santa Teresa a partir de algumas características da sua humanidade, em consonância com a homilia de Paulo VI na proclamação da Doutora da Igreja. Em seguida, traz aspectos históricos da importância da doutrina teresiana para a espiritualidade cristã. Explicita os fundamentos teológicos que possibilitaram o reconhecimento do doutorado das mulheres, no século XX, e dá as razões do doutorado teresiano, em contraste com a misoginia experimentada pela Santa em seu tempo histórico. Finaliza com os desdobramentos deste acontecimento para a teologia.

PALAVRAS-CHAVE: Santa Teresa de Ávila. Doutora da Igreja. Teologia. Mulher.

\begin{abstract}
This article addresses the proclamation of St. Teresa of Avila as a Doctor of the Church in 1970. It expands on some of the meanings of this event for theology,especially for the relationship between this knowledge and women. It begins by presenting the figure of Saint Teresa based on some characteristics of her humanity, in line with the homily of Paul VI in her proclamation as a Doctor of the Church. Then, it brings historical aspects of the importance of Teresian doctrine for Christian spirituality. After that, it explains the theological foundations that enabled the recognition of women's doctorate in the 20th century, and gives the reasons for the Teresian doctorate, in contrast with the misogyny experienced by Saint Teresa in her historical time. It concludes with the explanations of this event for theology.
\end{abstract}

KEYWORDS: Saint Teresa of Avila. Doctor of the Church. Theology. Woman.

* Pontifícia Universidade Católica do Rio de Janeiro, Rio de Janeiro, Rio de Janeiro, Brasil. 


\section{Introdução}

A Igreja celebrou, em 2020, os 50 anos de Santa Teresa de Jesus como A Doutora da Igreja. Primeira mulher a ter o doutorado oficial reconhecido, Teresa de Ávila foi seguida por Santa Catarina de Sena e, décadas mais tarde, por Santa Teresinha de Lisieux e Hildegarda de Bingen. $\mathrm{O}$ jubileu teresiano teve como contexto a pandemia do novo coronavírus, a COVID-19. Por esse motivo, eventos e publicações tiveram suas datas alteradas ou foram redimensionados. Mas nada conteve a força simbólica desta comemoração; ao contrário, o difícil momento epocal evocou particular consciência da ancoragem histórica da teologia.

O presente estudo está dedicado à primeira Doutora da Igreja, Santa Teresa de Jesus. Com ela, a antiga instituição eclesial, Doutor da Igreja, de escassa ressonância, recebeu um novo impulso e atraiu a atenção da teologia. $\mathrm{O}$ objetivo do artigo é aprofundar alguns significados desse doutorado para a teologia e, especialmente, para a relação entre este saber e as mulheres. Estrutura-se em quatro pontos. Inicia apresentando a figura de Santa Teresa a partir de algumas características da sua humanidade, em consonância com a homilia de Paulo VI na proclamação de Teresa como doutora da Igreja. Em seguida, traz aspectos históricos da importância da doutrina teresiana para a espiritualidade cristã, evidenciando como a recepção carismática dos seus escritos não se refletiu em reconhecimento oficial do doutorado devido à sua condição de mulher. Em seguida, explicita os fundamentos teológicos que possibilitaram o doutorado das mulheres, no século XX. Por último, dá as razões do Doutorado, contrastando-as com a misoginia experimentada pela Santa em seu tempo histórico, e aponta para os desdobramentos deste acontecimento.

\section{Sabedoria das coisas humanas e divinas}

Na homilia do Doutorado teresiano, Paulo VI ressaltou a "sabedoria das coisas divinas e sabedoria das coisas humanas" (PAULO VI, 1970b) que a união com Deus, tanto quanto é possível experimentar nesta terra, concedeu a Santa Teresa. Expressão feliz, que demonstra como a dialética entre a busca-experiência de Deus e as circunstâncias da vida geram, como gerou em Teresa, uma sabedoria das coisas humanas.

A sabedoria das coisas divinas e humanas faz desta espanhola do século XVI, religiosa Carmelita e primeira Doutora da Igreja, uma mulher inspiradora, com uma atualidade que não pode ser percebida a partir da espiritualidade pré-conciliar, demasiadamente fixada nas experiências extraordinárias, com desvalorização ou mesmo invisibilização da vida ordinária. Algumas características ilustram o mosaico humano desta figura transformada pelo Espírito. 


\subsection{Mística fundada na Humanidade de Cristo}

A mística de Santa Teresa possui uma dimensão trinitária, aprofundada ao longo da sua vida. A experiência cristológica foi decisiva e ponto de partida para o aprofundamento dessa experiência trinitária, porque provocou uma verdadeira redescoberta de Deus (PEDROSA-PÁDUA, 2015, p. 235-276). A percepção interna da humanidade de Cristo a marcou definitivamente, Teresa o chamava de "Humanidade sacratíssima" (V 22,6) ${ }^{1}$, com " $\mathrm{H}$ " maiúsculo, a modo de título. A oração teresiana era dialógica e relacional com o Jesus dos Evangelhos, em sua Humanidade. Esta experiência realiza nela um processo de humanização que projeta luz teologal e ética sobre as realidades da vida, do corpo, das relações humanas baseadas no amor efetivo, da forma de lidar com o mundo material e com a natureza. Com tudo isto, não é possível separar mística e humanização, na experiência teresiana.

\subsection{Lucidez, coragem e profetismo}

Teresa viveu um tempo de grande poder político e econômico espanhol, um contexto expansionista de conquistas geográficas e avanços em importantes áreas do conhecimento científico, filosófico, literário, cultural, conhecido como século de ouro na Espanha. Mas, logo percebeu que, para as mulheres audazes como ela, eram "tiempos recios" (V 33,5)2, tempos difíceis. Sua vida se desenvolveu em um contexto oficial radicalmente antifeminista e inquisitorial, que alimentava desconfianças com relação às mulheres, sempre que elas escapavam do modelo feminil vigente. No entanto, Teresa não se intimidou. Penetrou no mundo de forma ativa e com visão transformadora. Reformou a Ordem Carmelita, fundou a Ordem religiosa dos Carmelitas Descalços, exerceu intensa atividade de ordem material nas fundações, estabeleceu inúmeras e diversas relações humanas e escreveu muitos livros.

O interesse eclesial de Santa Teresa se fez social e político. Seu desejo de paz se faz ver na carta de Teresa a Dom Teutônio de Bragança, arcebispo de Évora. Ali vemos a Santa preocupada com os rumos do Reino de Portugal. Interpela o arcebispo a intervir diretamente em favor da paz, buscando acordos. Nesta carta, Teresa teme a guerra, que traz a morte e

\footnotetext{
${ }^{1}$ Utilizamos, neste artigo, as Obras Completas de Santa Teresa d'Ávila, das Ed. Paulinas (2018); as exceções são indicadas. Para as Cartas, fazemos uso da edição Carmelitanas/Loyola (1995) das Obras Completas de Santa Teresa de Jesus e as citamos pelo número constante nessa edição. As citações de Caminho de Perfeição, Fundações, Castelo interior ou Moradas, Relações e Livro da Vida seguirão a forma clássica e universal que indica: a obra teresiana abreviada (as siglas encontram-se ao final do artigo) seguida do número do capítulo e, após a vírgula, o número da parte do capítulo; na citação do livro Castelo interior ou Moradas, o número que antecede a sigla corresponde à morada respectiva. Esta forma de citar possibilita ao leitor/a conferir o texto a partir da edição que possui em mãos.

${ }^{2}$ Cf. edição espanhola das Obras Completas de Santa Teresa (Ed. Monte Carmelo, 1998).
} 
uma situação negativa para os cristãos: "em tempos em que há tão poucos cristãos, acabarem-se uns aos outros é grande desventura" (Cta. 293).

Na América, as barbaridades da colonização não lhe passaram desapercebidas. As notícias mais decisivas lhe chegaram pela visita de Frei Alonso Maldonado, franciscano, seguidor de Bartolomeu de Las Casas, defensor inflamado da causa dos indígenas em Madri e em Roma. A escritora se refere a ele como "servo de Deus, com os mesmos desejos" que ela (F 1,7). Através de Frei Alonso, seguramente teve conhecimento da violência da conquista das "Índias" e da situação dos indígenas (cf. Cta. 25). A narrativa testemunha tristeza, dor e oração intensas que resultaram em fortíssimo desejo missionário e martirial e, pouco tempo depois, em novas e sucessivas fundações. É possível afirmar que seu contato com as graves notícias da América, para onde haviam partido seus irmãos, está na raiz motivacional da sua expansão de fronteiras geográficas através das fundações dos Carmelos Descalços na quase totalidade da Espanha.

Sua relação com os pobres se fez profunda quanto mais se aprofundaram a contemplação e o seguimento de Cristo. Trata-se de um caminho espiritual, um "dom dado por Deus" (R 2,4) que realiza uma conversão. Uma solidariedade lhe brota de dentro, de um coração que passa a sentir diferente e uma mente aberta a um novo pensar. A pobreza torna-se para ela um compromisso de novas relações, pautadas na igualdade e na solidariedade. Atualizando esta exigência para o seu contexto histórico e eclesial, institui em suas comunidades uma forma de vida não pautada pela diferença que vem das origens familiares e de riqueza daquelas estruturas sociais. Quem tiver a linhagem mais nobre nunca deve evocar o nome de seu pai; Teresa advoga a igualdade: "todas devem ser iguais" (C 27,6). A vida comunitária era caracterizada por estrita pobreza: "a pobreza que Santa Clara tinha em sua casa, se tem nesta" (V 33,13).

\subsection{Comunicação e habilidade literária}

A atividade escrita, variada e pujante de Santa Teresa doou à humanidade importantes obras da mística e espiritualidade cristãs, como o Livro da Vida, Caminho de Perfeição e Castelo Interior ou Moradas. Impelida à narração de suas fundações, deixou-nos preciosas crônicas de época e conselhos espirituais no livro das Fundações. Inspirada, aventurou-se em poesias. Próxima das pessoas, teceu uma rede de relações tanto familiar e de amizade quanto missionária, através de um espetacular epistolário, do qual infelizmente nos chegaram menos de quinhentas cartas. Várias outras obras menores (mas não menos importantes) completam sua obra.

Buscadora de uma linguagem atraente, Teresa se utilizou de imagens que atravessam os séculos: há símbolos arquetípicos, como o centro (do castelo interior) ou a metamorfose da borboleta, especificamente o bicho-da-seda (transformação); símbolos originais como o jardim (a pessoa), a comparação 
da oração com as formas de regar o jardim (sendo a primeira com a água do poço), o jardineiro (Deus), o palmito (símbolo antropológico que apoia a ideia do centro - o mais saboroso da pessoa encontra-se no mais íntimo e unido a Deus), a abelha (símbolo da humildade) e o bicho-da-seda (narrado enquanto alegoria batismal - a vida nova em Cristo); símbolos essenciais como a água e o fogo (referindo-se à ação de Deus) ou a terra (referindo-se à pessoa ou ao próprio Cristo); símbolos abrangentes e complexos como o castelo interior (a pessoa humana com seu dinamismo interno de busca-encontro com Deus). Imagens e alegorias que abrem a possibilidade de discursos diversos, interdisciplinares e inter-religiosos, e são inspiração para novos olhares das novas gerações (PEDROSA-PÁDUA, 2019, p. 245). Teresa é verdadeira escritora, tem o que dizer e a preparação para tal. Traduz, em sua vida e obra, e de maneira muito humana, a vocação à amizade com Deus e a relação intrínseca entre experiência mística, transformação interior e ação apostólico-ética (PEDROSA-PÁDUA, 2011, p. 33-43).

\subsection{Generosidade, inteligência e empatia}

Teresa é amiga do amor e da amizade. A boa qualidade das relações humanas é uma das sínteses do seu caminho de perfeição. Ao contrário da noção de santidade do seu tempo, que tendia ao silêncio e à sisudez, defende a conversa, o diálogo e a expressão de si: "quanto mais santas, mais conversáveis com suas irmãs"3 (C 41,7). Na prática, cuida da vida comunitária e cotidiana, da saúde das pessoas, das boas condições das casas que abrigavam suas comunidades. Basta-nos uma única carta, de seu gigantesco epistolário, para sentir a capacidade de estabelecer amizade, resolver assuntos práticos e criar redes de relações. A carta à sua amiga e priora de Sevilha, Maria de São José (Cta. 130) é um bom exemplo. Inicia sempre com uma saudação respeitosa: "Esteja com vossa reverência, filha minha, o Espírito Santo". Segue fortalecendo a comunicação: "Já respondi a suas cartas, que chegaram muito bem pelo correio; e muito me alegrei com elas". $\mathrm{O}$ interesse pela saúde está sempre presente no epistolário: "Por caridade escreva-me depressa dando notícias de sua saúde". Noticia a troca de alimentos, intensa entre os conventos, "o atum que mandaram de Malagón (...) estava ótimo" e sobre amigas leigas em comum (dona Guiomar, dona Luísa), e termina com a administração da casa: "procure pagar a casa (...) para não terem de pagar tantos juros, pois fica muito pesado". Capacidade dinâmica e empática não lhe faltam.

Amiga também das ciências, considerava muito "ter letras" e rejeitava devoções tolas (V 13,16). Pelas cartas, torna-se interessante constatar o conhecimento vasto de Santa Teresa da medicina caseira, bem como as suas

\footnotetext{
${ }^{3}$ Neste artigo, as obras teresianas indicadas apenas com a sigla, com exceção das Cartas, seguem a edição brasileira das Obras Completas das Ed. Paulinas (2018). As Cartas são citadas segundo a edição brasileira das Obras Completas das Ed. Carmelitanas e Loyola (1995). Nas exceções, indicam-se as edições.
} 
intuições sobre a saúde psíquica. Não tinha boa saúde, "quando tenho apenas os males ordinários, considero-me com muita saúde" (Cta. 63), mas cuidava-se e cuidava dos demais, em especial das irmãs em seus conventos. A mãe de Teresa morrera aos trinta e três anos de idade, após nove filhos; a Santa de Ávila vem a falecer com sessenta e sete anos, bem acima da média de seu tempo. O cuidado está certamente na raiz desta longevidade. Conhecia receitas para males diversos, folhas e ervas para infusões e purificações. "Tirei um pouco da resina (...) as pastilhas com açúcar rosado me fazem muito bem aos resfriados" (Cta. 174), escreve à sua amiga Maria de São José, em uma de suas inúmeras referências às receitas caseiras. Observa as coisas simples, cuida dos detalhes. Em uma carta ao irmão, sua empatia e solidariedade para com o seu tio Pedro se materializa num pequeno braseiro manual: "como fica muito tempo na Igreja, deve sentir frio nas mãos" (Cta. 171). A saúde psíquica, tristeza e melancolia (que ela não queria em suas casas) não lhe passavam desapercebidas, bem como as etapas da vida: "tenho pesar da doença de Encarnação, mas são males que com a idade vão passando" (Cta. 192); na mesma carta, a atenção à Priora doente: "à Priora com febre, não convém pedir-lhe nada por enquanto". Exemplos como estes se multiplicam na leitura do epistolário teresiano.

A humanidade de Teresa inclui admirável bom humor, mesmo diante das maiores perseguições à sua Ordem: "realmente esses nossos negócios servem para nos fazer conhecer o mundo: não parece outra coisa senão uma comédia." (Cta. 179). Bom humor também diante das fofocas: "Muito desgosto me deu estar Nosso Padre apurando os ditos contra nós, especialmente sendo tão desonestos; são disparates, e o melhor é rir-se deles e deixar falar" (Cta. 180).

Amiga da recreação e das artes, vemos Teresa solicitando ao seu irmão, Lourenço de Cepeda, canções de Natal de melhor qualidade ("os daqui não têm pés nem cabeça", Cta. 165), para que as irmãs pudessem ouvir e cantar uma boa música. Convidou o austero São João da Cruz para aprender, com seus conventos, o "estilo de irmandade e recreação em comum" (F 13,5). Escreveu poesias para a recreação, compartilhou-as entre os conventos e com familiares. Em uma carta a Lourenço envia, humildemente, para sua recreação, talvez sua melhor poesia mística: “Ó formosura que excedeis a todas as formosuras..." (Cta. 165).

Teresa é amiga da vida. Isto se expressa até em seu sinete, com o qual selava as cartas no séc. XVI, apertando-o contra a cera. Na ocasião em que a Santa perdera seu carimbo predileto, que trazia o monograma de Jesus, JHS, sobrou-lhe apenas outro carimbo, que trazia uma caveira, símbolo da efemeridade da vida, da eternidade, do juízo rigoroso e próximo. Um símbolo muito comum em seu tempo. Numa carta ao irmão, pede-lhe que envie rapidamente o seu carimbo preferido e desabafa: "não suporto selar com esta morte". Quisera apenas selar "com aquele que eu quisera estivesse no meu coração..." (Cta. 165). 
Há em Santa Teresa uma humanidade profética e empática. Nos exemplos acima é possível intuir algo desta "sabedoria das coisas divinas e sabedoria das coisas humanas" de que falava Paulo VI, que é percebida por leitores e leitoras ao longo dos séculos, a testemunhar a autenticidade da profunda experiência de Deus narrada em suas obras doutrinais.

\section{Reconhecimento histórico da doutrina teresiana até a atualidade}

Paulo VI inicia a Homilia do Doutorado teresiano com palavras significativas: "Nós conferimos, ou melhor, nós reconhecemos o título de Doutora da Igreja a Santa Teresa de Jesus" (PAULO VI, 1970b). Fica claro que se trata do reconhecimento oficial de uma autoridade magisterial já aceita no interior da Igreja. O título não faz a Doutora, mas ao contrário.

\section{1 Êxito editorial e amor pelas obras desde os princípios}

É possível dizer que o doutorado teresiano foi preparado nos quase cinco séculos que nos separam da primeira edição das obras de Santa Teresa, em 1588. O povo cristão, com seu sensus fidei, respondeu com entusiasmo ao convite que a escritora fez à experiência de Deus e percebeu, nela, aquela sabedoria das coisas divinas e humanas. A permanência da mensagem da doutora da Igreja e sua influência na espiritualidade cristã podem ser constatadas pela sua expressiva presença editorial. O grande teresianista Tomás Álvarez (ALVAREZ, 1995, p. 685) nos deixou os dados sobre o número de edições totais ou parciais das obras da Santa: século XVI, 12 edições; século XVII, 191; século XVIII: 99; século XIX: 200; século XX (até 1960): 340. As edições totais se dão nas majoritárias línguas europeias; as parciais, numa plêiade linguística como o árabe, bengali, malaio, catalão, grego, latim, tâmil, coreano, malgaxe, etc. A bibliografia amplia-se consideravelmente com a proclamação do doutorado. Apenas no ano de 1970 houve 30 novas edições (SIMEON DE LA S. FAMILIA, 1971, p. 413ss). Em português do Brasil, temos, atualmente, traduções das Obras Completas ${ }^{4}$ ou parciais, totalmente acessíveis aos leitores. O êxito editorial demonstra o apreço pelos escritos teresianos e a influência do magistério da autora ${ }^{5}$.

As obras foram custodiadas com carinho. Primeiramente, pela própria Santa. Com exceção de Conceitos do amor de Deus (ou Meditação sobre o Cântico dos Cânticos, queimado por Teresa a pedido do primeiro leitor e censor) e da integridade das Cartas (já não mais em poder dela), foram

\footnotetext{
${ }^{4}$ Para as Obras Completas, vide Referências bibliográficas, ao final.

${ }^{5}$ No século XX, o Editorial Monte Carmelo (Burgos) realizou edições faccsimiles de obras principais de Santa Teresa. Em 2002, o teresianista Tomás Álvarez presenteou generosamente a PUC-Rio com uma edição limitada em Fac Simil do Libro de la Vida, que se encontra na biblioteca dessa Universidade.
} 
conservados os autógrafos de seus livros. Ela mesma reconhecia o valor deles - o que revela uma autoconsciência do seu magistério -, como se pode verificar nos elogiosos títulos do Livro de Vida: "é muito proveitoso" (cap. 11, 13, 15, 22, 25, 28); "é bastante de notar" (cap. 14, 18, 27, 28, 34); "são muito necessárias e proveitosas as coisas que aqui se tocam" (cap. 15); "é para animar muito os que tratam oração" (cap. 18); "se declara por muito delicado modo" (cap. 18); "é de muita admiração" (cap. 20); "tem boa doutrina" (cap. 21, 25); "bastante boa doutrina" (cap. 37); "se declara muito bem" (cap. 25); "coisas bastante boas para aviso" (cap. 31).

As carmelitas copiaram os manuscritos com amor e os liam nos refeitórios.

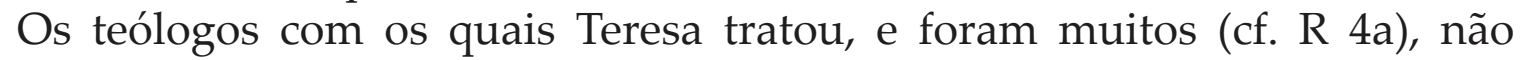
encontraram nas obras nada contra os evangelhos ou o concílio de Trento, ao contrário. A inquisição, que tanto fez a Madre Teresa sofrer, não pode censurar nenhuma de suas páginas.

A imprensa ampliou as possibilidades de leitura das obras da Santa, o que se deu de forma privilegiada a partir da edição princeps das obras completas, por Frei Luis de Leão (1588), cujo prólogo contém um reconhecimento do estilo da linguagem teresiana (facilidade, graça e compostura das palavras, além de uma "elegância desafeitada" que delicia) e de uma especial inspiração do Espírito Santo nos livros:

Sempre que os leio novamente fico admirado. Em muitas partes deles me parece que o que escuto não é engenho humano; não duvido que, em muitos lugares, era o Espírito Santo que falava e lhe regia a pluma e a mão. O fogo que as suas palavras acendem no coração de quem as lê e a luz que jogam sobre coisas escuras manifestam esta ação do Espírito (ALVAREZ, 1995, p. 686, tradução nossa).

\subsection{Reconhecimento do valor magisterial das obras de Santa Teresa}

Muitos são os testemunhos históricos do reconhecimento do valor magisterial da obra teresiana. Em sua imensa biblioteca de El Escorial, o rei Filipe II conservou os autógrafos de Vida e Caminho de Perfeição (1 $1^{\underline{a}}$ redação) junto com livros, julgados originais, de dois doutores da Igreja, Santo Agostinho e São João Crisóstomo. Por sua vez, os processos de beatificação e canonização de Santa Teresa firmam a convicção e afirmam, de maneira oficial, o caráter carismático dos seus escritos e o poder transformador sobre quem os lê.

Os artistas, desde cedo, a retrataram escrevendo, inspirada pelo Espírito (simbolicamente retratada pela luz ou a presença de uma pomba). Valorizaram sua doutrina e mensagem. São encontradas, em profusão, pinturas e esculturas de artistas importantes (Zurbarán, Velazquez, Gregorio Hernández) desde o século XVII. Foram os primeiros a reconhecer o seu doutorado, podemos dizer. No Museo Santa Teresa, em Ávila, podem ser encontradas gravuras do século XVII que representam a doutora na cátedra de Salamanca a ensinar os teólogos, entre dominicanos, jesuítas, carmelitas, franciscanos e outros, com quem Teresa conversou e se aconselhou. Estes 
a escutam atentamente. Releituras artísticas atualizam a percepção sobre Santa Teresa e a tornam presente ao longo da história, como a famosa escultura do "Extase", de Bernini, a "andariega" de E. Cruz Solis, a doutora mística de Emilio Sánchez, a cidadã abulense de Óscar Alvariño, para dar alguns exemplos. Não é possível descrever aqui a abundância de obras literárias, teatrais e cinematográficas a ela dedicadas.

A Carta Apostólica Multiformis Sapientia Dei, de Paulo VI (1970a), que a proclama Doutora da Igreja, recolhe o nome de "homens de grande prestígio" que a conheceram e tiveram por santa e mestra: Pedro de Alcântara, Francisco de Borja, João da Cruz (também santo e doutor da Igreja), João de Ribera, João de Ávila. Igualmente, refere-se aos santos que receberam sua influência e a veneraram, Francisco de Sales e Afonso de Ligório (ambos santos e doutores da Igreja), Antonio Maria Claret, Carlos de Setia e Vicente Pallotti. E sublinha a grande influência de seus escritos para a Teologia Espiritual.

De modo especial, a escola francesa de espiritualidade, a partir do século XVII, recebeu grande influência das obras teresianas. Até à espiritualidade moderna, com Teresa de Lisieux e Carlos de Foucauld (ALVAREZ, 1995, p. 688).

A Universidade de Salamanca concedeu à Santa de Ávila o título de Doutora Honoris Causa, em 1922. A proclamação foi seguida de expressões populares que fortalecem a legitimidade desse título; entre elas, um grupo de mulheres "presenteou" a Santa com um barrete de doutora, todo adornado em pedrarias, como pode ser visto no museu do Convento da Encarnação, em Alba de Tormes.

Vários papas se referiram à doutrina teresiana: Gregório $\mathrm{XV}$, ao canonizar a Santa, louvou o "espírito de inteligência" e de "celestial sabedoria" que irrigam sua doutrina; Bento XIII, ao canonizar São João da Cruz, comparou-o a Santa Teresa - "foi instruído de igual maneira a como o foi Santa Teresa"; Pio X a comparou aos grandes Padres e doutores da Igreja (Gregório Magno, João Crisóstomo, Anselmo de Aosta) e, em Carta Apostólica, afirmou que "a Igreja se acostumou a tributar [a Santa Teresa] honras próprias de doutores" (1914); Bento XV, em discurso aos cardeais (1921), proferiu que Teresa uniu a coroa da santidade à grinalda da doutrina; Pio XI, em constituição apostólica (1922), a chamou "mãe sapientíssima" e "mestra sublime da contemplação"; Pio XII, em sermão (1951) afirmou que, por Santa Teresa, o Espírito Santo entregou à Igreja um tesouro de doutrina espiritual; João XXIII a chamou de luz singular da Igreja, em Carta apostólica de 1962 (PAULO VI, 1970a).

\subsection{Obstat sexus}

Diante de tudo isto, os leitores modernos podem se perguntar: por que Santa Teresa não foi declarada Doutora da Igreja, oficialmente, antes? É possível perceber não apenas o valor de seus escritos, mas também uma influência permanente de sua doutrina na Igreja! Esta possibilidade foi 
levantada algumas vezes na história. Pio XI, por ocasião do processo de declaração de São João da Cruz Doutor da Igreja, foi interpelado neste sentido, pela própria Ordem Carmelitana. A solicitação foi recusada. O motivo permanecia o mesmo, a saber, a tradição, que afirmava o impedimento imposto pelo sexo (ALVAREZ, 1995, p. 695), segundo o interdito explícito de São Paulo de que as mulheres não podem ensinar em público (1Cor 14,34 e 1Tm 2,11-12). Enfim, obstat sexus - o sexo o impede.

\section{Fundamentos teológicos do doutorado feminino}

O doutorado eclesial exige três elementos: santidade de vida, doutrina eminente e proclamação oficial. Santa Teresa contava com os dois primeiros. A rápida canonização, quarenta anos após sua morte, junto com Santo Inácio de Loyola, São Francisco Xavier, Santo Isidoro e São Felipe Neri, atestara a sua vida santa; o reconhecimento de sua doutrina pela tradição garantia a segunda condição. Faltava-lhe a proclamação oficial. Alguns aprofundamentos e transformações na consciência eclesial se fizeram essenciais para tal.

\subsection{Ventos do Espírito na hermenêutica bíblica (e já presentes na mística teresiana)}

O doutorado feminino contava com barreiras teológicas históricas, como visto acima. O impedimento do sexo se fazia premente. Por isso, estudos precederam a declaração do doutorado da primeira mulher. A linha seguida, de forma preponderante, foi reforçar a distinção entre o magistério que advém da doutrina dos doutores e o magistério eclesiástico, autoridade na Igreja. E assim aparece na homilia da Proclamação: o "preceito apostólico" de 1Cor 14,34 não foi violado, pois não se trata de um "título que comporte funções hierárquicas de magistério" (PAULO VI, 1970b). Um artigo de K. Rahner, da mesma época, mostra outra linha de interpretação. Não procurou motivos para salvar o preceito. Para o teólogo, o doutorado teresiano mostra como a norma paulina é condicionada pelo seu tempo histórico e como a ausência de mulheres doutoras se deve a uma (infra) valorização cultural e histórica da mulher (RAHNER, 1970, p. 310).

O texto paulino poderia receber iluminação da própria Doutora, que faz referência, embora indireta, a 1Cor 14,34 e 1Tm 2,11-12. A Santa sempre esteve diante da necessidade de discernir sua missão. Dentro dela estavam o desejo de nunca ir contra a Sagrada Escritura e, ao mesmo tempo, de cumprir a vontade de Deus, que suscitava nela contribuir com a renovação da Igreja, através das fundações, e a impelia à redação de seus livros. Mas, por outro lado, ela conhecia (e faziam questão de lhe lembrar) os textos em que São Paulo proíbe à mulher falar em público e indica a submissão dessa ao varão. É neste contexto que lhe vem a iluminadora experiência interior narrada abaixo. 
Conta-nos ela que um dia (por volta de 1571, Teresa contava com cerca de 56 anos) estava ponderando se aqueles que julgavam fosse coisa ruim que ela saísse a fundar não estariam com a razão; encerrar-se não seria, de fato, a vontade de Deus? É quando escuta a iluminadora voz do seu Mestre interior: "Dize-lhes que não se conduzam somente por uma passagem da Escritura, mas que olhem outras e vejam se porventura poderão atar-Me as mãos." (R 19) ${ }^{6}$. Certamente clarificou-se, em sua mente e coração, a contradição entre o preceito paulino e o que ela conhecia dos Evangelhos, em que Jesus não colocava travas à ação das mulheres ou exigia delas submissão aos varões; ao contrário, Teresa vê nas mulheres uma fé audaciosa! A iluminação do Mestre interior continua em tom pneumático, a desafiar o pensar comum: é possível atar as mãos de Cristo? Sabia bem a Santa qual era a resposta a esta pergunta, e era um sonoro "não".

\subsection{Concílio Vaticano II: afirmação do múnus profético do Povo de Deus e do valor da mística}

Além das discussões da teologia paulina, e iluminando-as, estão o grande evento do Concílio Vaticano II e seu contexto. Em seu diálogo com a modernidade, assumiu algumas das motivações feministas e trouxe novas pneumatologia e teologia. Foi pouco após a clausura do Concílio que o Papa Paulo VI surpreendeu a Igreja, num discurso espontâneo durante Congresso do Apostolado dos Leigos. Anunciou sua intenção em declarar Santa Teresa de Jesus e Santa Catarina de Sena Doutoras da Igreja. Duas "mulheres de um feminismo cristão autêntico, duas santas de fama universal, duas místicas com mensagem para a Igreja" (ALVAREZ, 1995, p. 684). Ambas com espiritualidade centrada em Jesus Cristo e, ao mesmo tempo, sujeitos de grande dinamismo apostólico e eclesial.

A proclamação do doutorado, neste contexto, é uma confirmação solene do múnus sacerdotal de todo o Povo de Deus, que exige professar a fé (LG 11) e do múnus profético pelo qual todos são ungidos pelo Espírito para o ato de fé, fora dos estreitos limites da hierarquia (LG 12). Ambos aspectos foram mencionados na proclamação de Santa Teresa Doutora: o primeiro na Homilia (PAULO VI, 1970b); o segundo, na abertura da Carta Multiformis Sapiencia Dei (PAULO VI, 1970a). O texto conciliar resgata um antes esquecido versículo paulino (da mesma carta que tantos problemas havia trazido, sobre a submissão da mulher ao varão), de caráter pneumatológico, no qual se afirma que o Espírito Santo santifica e conduz o Povo de Deus, repartindo seus dons "a cada um como lhe apraz" (1Cor 12,11), e o comenta: não "apenas através dos sacramentos e ministérios" (LG 12). Por ele, todos os fiéis, inclusive as mulheres e todos os cristãos

\footnotetext{
${ }^{6}$ Aqui, excepcionalmente, preferimos utilizar a tradução da edição Carmelitanas/Loyola (1995) das Obras Completas de Santa Teresa de Jesus, por ser mais fiel ao original do texto do livro das Relações.
} 
leigos, são capacitados para assumir ofícios e trabalhos que contribuem para a renovação da Igreja. Ressoam oficialmente, no século XX, as palavras do Mestre interior para Santa Teresa, já mencionadas acima: “...porventura poderão atar-me as mãos" (R 19) ?

Outro elemento importante do Concilio é a valorização da experiência mística como carisma eclesial para enriquecer a tradição, pela compreensão "das coisas" e "das palavras" de Deus.

[...] cresce, com efeito, a compreensão tanto das coisas como das palavras transmitidas, seja pela contemplação e estudo dos que creem, os quais as meditam em seu coração (cf. Lc 2,19 e 51), seja pela íntima compreensão que desfrutam das coisas espirituais [...] (DV 8)

A teologia conciliar considera a mística uma forma de participação na função profética de Cristo, um serviço à renovação e à edificação da Igreja, e um enriquecimento na compreensão e transmissão da Revelação. Por ser testemunho vivo de Cristo ao mundo, é também serviço à teologia e à Igreja. Assim sendo, quem se ocupa da mística ocupa-se de teologia, fala a partir de uma Palavra revelada, comunica algo à Igreja, contribui para a vida em Cristo.

Trata-se do reconhecimento do aspecto carismático-experiencial no magistério institucional. Experiência espiritual e doutrina estão unidas, nos diz o doutorado teresiano, concretização do texto conciliar. Mística e dogmática se orientam mutuamente, exigem-se e se criticam, como bem alertou Schillebeeckx, ao comentar a proclamação (SCKILLEBEECKX, 1970, p. 319-320). A separação entre teologia e mística gera grave distorção no discernimento da experiência mística, por um lado, e na intencionalidade da teologia, por outro. A mística torna a Igreja consciente de que as próprias estruturas institucionais não são o seu sentido final; tampouco o são suas (necessárias) teologias. O sentido final da Igreja está na comunhão com Deus, com toda a humanidade e com o cosmos.

Mas, certamente, o elemento instigante do doutorado teresiano é a mulher doutora, pela primeira vez. Novidade numa instituição antiga e, pode-se dizer, de relevância limitada. Pela aprovação solene e irrevogável do múnus magisterial da mulher na Igreja, dá-se uma revalorização do papel e da palavra das filhas de Eva na comunidade eclesial.

\section{Razões do doutorado teresiano: o que aprender com ele}

A homilia de Paulo VI destaca algumas razões do doutorado teresiano: a atualidade de sua mensagem sobre a oração, a dignidade da mulher na Igreja e a eclesialidade da Santa. Mas os frutos foram além e demostram

\footnotetext{
7 Segundo tradução da edição Carmelitanas/Loyola (1995) das Obras Completas de Santa Teresa de Jesus, livro das Relações.
} 
inúmeras virtualidades teológicas das obras de Teresa de Jesus. O que aprender com essas razões?

\subsection{Atualidade e universalidade da doutrina teresiana sobre a oração}

Dentre as razões do doutorado de Santa Teresa, Paulo VI destacou a atualidade da mensagem teresiana sobre a oração, realizada a partir de seu testemunho místico e com fina pedagogia (PAULO VI, 1970b).

De fato, os escritos teresianos trazem o tema da oração sob várias perspectivas. Primeiramente, narram a experiência e aprendizado da própria Santa sobre a oração, marcados por crises e avanços (cf. R 4,12). Diante dos olhos do/a leitor/a são encontradas, no Livro da Vida, as inesquecíveis experiências da infância, as dificuldades e fracassos na oração, a forma como Teresa buscou recursos para auxiliá-la, os modelos bíblicos para a oração, os símbolos encontrados para expressar-se, a passagem de uma oração ascética para uma oração mística, sendo a primeira mais associada ao esforço e busca de Deus (mas sempre como resposta à ação misteriosa divina, o que mostra como a dimensão mística está presente mesmo no esforço da oração) e a segunda, oração mística, marcada por especial experiência da presença gratuita de Deus no interior de si própria, mas que não exclui o esforço hermenêutico e ético $(\mathrm{V}$ 10,1). A experiência se aprofunda e purifica, sempre na relação com Jesus Cristo, "livro vivo" (V 26,5); a partir dele, desemboca, em período mais tardio na vida da Santa, na experiência da realidade trinitária (7M 1).

Além da narração da própria experiência, há uma teologia da oração. A tradição e os estudos teresianos costumam ver essa doutrina condensada na expressão em que Teresa de Jesus diz, com agudeza e simplicidade, que, em seu parecer, a oração mental não é outra coisa senão "tratar de amizade, estando muitas vezes tratando a sós com quem sabemos que nos ama" (V 8,5). Nesta oração, há um elemento original de Santa Teresa, a saber, o deslocamento do conceito de oração como meditação ao conceito de oração como relação, e relação de amor (cf. C 28,3). A oração-amizade é uma prática oracional cultivada a sós e de maneira frequente com Jesus Cristo, Humanidade sagrada (V 12,2; 22,6). Claro está que ela não suprime ou desvaloriza a oração comunitária; trata-se aqui de ressaltar a importância da oração-relação que afeta o sujeito, provoca amadurecimento humano-espiritual e transforma a vida. E mais que uma prática. É uma forma de vida em permanente relação de diálogo com Deus, em que cabem todas as modulações da oração cristã, como adorar, oferecer, pedir, escutar, amar, contemplar, esperar, etc. Cristo faz-se companheiro de caminho: "Juntos andemos, Senhor. Por onde fordes, tenho de ir. Por onde passardes, tenho de passar" (C 26,6). Por isso, a oração como amizade transforma a pessoa e coloca em movimento os melhores dinamismos interiores (HERRAIZ GARCIA, 2002, p. 55). Pela oração faz-se e refaz-se a história pessoal, o 
amor inicial amadurece em direção à união mística e inseparável com Deus, que Santa Teresa chama de "matrimônio espiritual" (7M 2,1), através de Jesus Cristo, no Espírito. A cada etapa aprofundam-se e radicalizam-se o compromisso ético, o amor concreto aos irmãos e irmãs e a busca de um projeto coletivo, eclesial e social.

À narrativa da experiência oracional e à teologia da oração, somam-se, na doutrina teresiana, também uma pedagogia e uma mistagogia da oração. Pela pedagogia, o/a orante aprende a interiorizar a oração pessoal pelo recolhimento, a cultivar as capacidades de uma amizade (C 26-29) e a desenvolver atitudes e virtudes evangélicas, como a humildade, o desapego, o amor concreto (C 4-15) e a "determinada determinação" (C 21,2). Pela mistagogia, Teresa de Jesus busca aproximar o/a leitor/a do mistério de Deus no qual ela própria está imersa. Para isso, Teresa ensina a oração orando. Assim, envolve o/a leitor/ que, ao sintonizar e empatizar com a experiência teresiana, é também introduzido na experiência oracional e mística da Santa, intuindo-a e fazendo-se dela partícipe.

A atualidade da oração teresiana se fez apenas confirmar. De maneira particular, o elemento dialógico, essencial na experiência orante, marca a influência teresiana no magistério eclesiástico posterior $(\mathrm{CIgC} 2704$ e 2709). Ultimamente, a Exortação do Papa Francisco, Gaudete et exsultate, sobre o chamado à santidade no mundo atual, afirma a necessidade de tempos dedicados à oração, no silêncio e na solidão diante de Deus. Recolhe literalmente a definição teresiana de oração pessoal e ressalta tanto a universalidade quanto a necessidade desta experiência:

Para Santa Teresa de Ávila, a oração é "uma relação íntima de amizade, permanecendo muitas vezes a sós com quem sabemos que nos ama". Gostaria de insistir no fato de que isto não é dito apenas para poucos privilegiados, mas para todos [...]. A oração confiante é uma resposta do coração que se abre a Deus face a face, onde são silenciados todos os rumores para escutar a voz suave do Senhor que ressoa no silêncio. Neste silêncio, é possível discernir, à luz do Espírito, os caminhos de santidade que o Senhor nos propõe (GeE 149 e 150).

O interesse contemporâneo pela oração e o reconhecimento da Doutora da Igreja como mestra da oração são indicados pela profusão editorial de Santa Teresa na atualidade. Os símbolos, pelos quais Teresa expressa sua aventura interior, continuam encantando gerações de várias latitudes. Igualmente encanta a capacidade da autora de, como mistagoga, tocar o abismo espiritual do/as leitore/as, incendiando-os com as arrebatadoras narrativas do grande sentimento de amor que a invade nas experiências oracionais místicas. Não apenas cristãos a leem e têm em Teresa de Jesus uma referência nos caminhos do espírito. Pessoas de outras religiões, ocidentais e orientais, e mesmo ateus e agnósticos se interessam pela experiência oracional teresiana e por sua teologia sobre a oração, registradas em suas obras com tanta beleza e verdade. Torna-se cada vez mais claro que Teresa é "patrimônio da humanidade" (SANCHO FERMIN; CUARTAS 
LONDOÑO; NAWOJOWSKI, 2016) e que a busca espiritual é uma das grandes características dos tempos atuais.

\subsection{Oficialização da palavra teológica da mulher na Igreja: duro aprendizado}

A segunda razão do doutorado, destacada por Paulo VI, é manifestar a dignidade da mulher e seu lugar na Igreja, especificamente para manifestar sua fé "com sua palavra e seus escritos" (PAULO VI, 1970b). É reconhecida sua missão insubstituível, fundada no batismo, de participar no aprofundamento e transmissão da mensagem do Evangelho e da doutrina teológica e espiritual da Igreja.

O fato de que a mulher estude, escreva e ensine teologia fica, com o doutorado teresiano, expressamente reconhecido. Não se trata de concessão ou permissão, mas de reconhecimento do múnus magisterial da mulher na Igreja. Reconhecimento que leva consigo a conclamação a que as mulheres, desta forma, colaborem com a graça divina para a instauração do Reino de Deus na terra.

Assim, mulheres teólogas têm, em Teresa de Ávila, como primeira doutora da Igreja, um testemunho vivo de que são não apenas benvindas, mas necessárias no mundo teológico. $\mathrm{O}$ caminho não é fácil, o machismo estrutural pode atingir também a Igreja e a academia. A trajetória da Santa, no século XVI, bem ilustra esta dificuldade, consciente que era, em seu tempo, da desqualificação da mulher $(C 21,2)$ e da sua sujeição ao varão (C 22,7; C 26,4). Teresa escreveu com humildade, sabedoria e autoridade, soube convencer e mesmo seduzir os melhores teólogos de seu tempo. Ainda assim, não foram poucas as censuras às suas obras, realizadas pelo primeiro leitor, em geral amigo da Santa, mas sempre censor.

Um exemplo teresiano se faz eloquente, como testemunho da desqualificação e silenciamento das mulheres. O livro Caminho de Perfeição, em sua primeira redação, traz uma oração dirigida a Jesus Cristo, diante do qual Teresa sempre se sentiu livre e favorecida. A Santa expressa indignação diante da situação das mulheres de seu tempo: estão "encurraladas"; o que testemunham é desqualificado em público; não podem falar aquilo que choram em segredo; os varões se tornam juízes de mulheres. Escrita hoje, seria claramente uma página chamada feminista. A censura não a perdoou, por machismo e por temor de problemas com as atividades inquisitoriais. O leitor riscou veementemente suas linhas (ALVAREZ, 1996, p. 491-504). Não fossem os séculos que desbotaram a tinta do censor, não conheceríamos este escrito representativo da mulher de fé, consciente e livre, crítica e audaz que foi Teresa de Ávila.

A oração censurada (isso mesmo, oração censurada) é a seguinte:

Nem aborrecestes, Senhor de minha alma, quando andáveis pelo mundo, as mulheres; antes as favorecestes sempre com muita piedade e achastes nelas 
tanto amor e mais fé que nos homens, pois estava vossa santíssima Mãe [...] Não basta, Senhor, que o mundo nos traga encurraladas [...] que não façamos nada por Vós que seja válido em público, nem ousemos falar algumas verdades que choramos em segredo? Não haveríeis Vós de ouvir petição tão justa? Não o creio, Senhor de bondade e justiça, pois sois juiz justo, e não como os juízes do mundo, que - como são filhos de Adão e, enfim, todos varões - não há virtude de mulher que não tenham por suspeita. (C 3,7, nota 9, p. 444)

Como todo texto profético, termina com o anúncio de novos tempos, em que "ânimos virtuosos e fortes" não serão desprezados:

Sim, que algum dia há de haver, Rei meu, que se conheçam todos. Não falo por mim, que já tem conhecido o mundo minha ruindade e eu folgado que seja pública; senão porque vejo os tempos de maneira que não é justo desprezar ânimos virtuosos e fortes, ainda que sejam de mulheres (C 3,7, nota 9, p. 444).

Diante das palavras lúcidas, críticas e libertadoras constantes na oração da Doutora da Igreja, é possível afirmar que o doutorado teresiano contribui para a alteração na orientação de silenciamento da mulher nos espaços teológicos e eclesiais, novos tempos que não podem ser desprezados. Tendências conservadoras e misóginas, ou mesmo a inércia preguiçosa e interessada, podem retardar o reconhecimento pleno da mulher na teologia, mas não poderão alterar o rumo do rio estabelecido de forma oficial e irrevogável.

\subsection{Eclesialidade: a fidelidade inclui o profetismo}

Finalmente, Paulo VI destaca a eclesialidade teresiana, o seu "sentir com a Igreja" (PAULO VI, 1970b). É bem conhecida uma das últimas frases da Santa, em seu leito de morte: "enfim, morro filha da Igreja". O crescimento na consciência eclesial levou Santa Teresa a dar respostas, criativas e inspiradas, às necessidades e aos males vividos por aquela Igreja do século XVI. Contribuíram para o desenvolvimento desta consciência vários fatores, sendo os principais, primeiramente, o conhecimento do rompimento da unidade cristã $(C$ 1,2) e, num segundo momento, a situação da colonização nas "Índias" (F 1,7-8). Teresa conseguiu motivar uma rede de comunidades e de pessoas empenhadas na mesma causa e alimentou, com os seus escritos doutrinais e cartas, a vida e a espiritualidade das comunidades e dos que gravitavam ao seu redor.

Mas nem sempre foi compreendida. Sabe-se que o Núncio apostólico, Felipe Sega, confundindo fidelidade à Igreja com subserviência cega, viu em Santa Teresa uma mulher perigosa e incômoda: "mulher inquieta e andarilha, desobediente e contumaz", que "inventa más doutrinas [...], ensinando como mestra e indo contra o ensinamento de São Paulo, de que as mulheres não ensinassem" (BANBRIDGE, 2000, p. 1011, tradução nossa).

\footnotetext{
${ }^{8}$ A oração consta apenas da primeira redação do livro Camino de Perfección, códice de El Escorial (CE 4,1). Censurada, não passou à segunda redação do livro homônimo, na qual as edições brasileiras baseiam suas traduções.
} 
Duro julgamento. Um exemplo de como atitudes preconceituosas e misóginas, acontecidas no interior da instituição, causam sofrimento [como causaram, efetivamente, à Santa], abafam a voz profética do Espírito e prejudicam a expansão do Reino de Deus. Teresa representava para ele uma mal-intencionada transgressora dos ensinamentos bíblicos, das regras eclesiásticas e do modo feminino comum de viver. Como se sentiria confundido ao vê-la reconhecida Doutora da Igreja, quase quinhentos anos depois. Sua descrição da Santa - "inquieta e andarilha" - é atualmente ressignificada como elogio. O Papa Francisco exortou a todos os cristãos, em 2015, a aprender da andarilha: "Na escola da santa andarilha aprendamos, também nós, a ser peregrinos" (FRANCISCO, 2014).

\subsection{Frutos para além das expectativas: o testemunho profético sempre fala}

Os frutos do doutorado teresiano foram além das expectativas. As celebrações do IV Centenário de morte de Santa Teresa, em 1982 e do V Centenário de seu nascimento, em 2015, ajudaram a constatar o florescimento contínuo dos estudos literários e doutrinais em torno à obra da Doutora da Igreja, com matizes distintos em duas etapas.

Uma primeira etapa coincide com o Concílio Vaticano II, passa pela proclamação do doutorado e culmina nas publicações do IV Centenário. Houve uma ampla releitura da obra teresiana à luz da teologia conciliar, liberando-a da leitura a-histórica e baseada em fenômenos extraordinários da espiritualidade da contrarreforma. O doutorado teresiano acolheu esta releitura. Uma nova luz foi concedida à figura e à obra de Santa Teresa. Coincidiu com uma maior sensibilização na teologia ao tema da experiência espiritual, valorização do testemunho dos místicos e reconhecimento de uma missão teológica nos seus escritos. Santa Teresa foi valorizada como mestra de oração, enraizada nas Sagradas Escrituras, na experiência dos grandes mistérios da salvação cristã e nos acontecimentos histórico-eclesiais. Percebeu-se como a experiência religiosa de Teresa rompeu fronteiras dentro e fora da Igreja. Foram valorizados seu pensamento e sua experiência, unidos intrinsecamente (CIRO, 2015, p. 480).

Coube a Jesús Castellano (CASTELLANO, 1982, p. 183-192) perceber como, nesta etapa, buscou-se uma recuperação dos conteúdos teológicos da experiência e doutrina teresianas, em parte devido ao veredito negativo de autores conhecidos, como A. Stolz, U. Von Balthasar e J. Maritain, que tenderam a reduzir a mística de Santa Teresa a uma experiência psicológica e subjetiva, sem enraizamentos bíblicos, eclesiais, litúrgicos ou patrísticos. Algumas das dimensões trabalhadas nesta etapa foram a doutrina e experiência trinitárias, a cristologia, a pneumatologia implícita (símbolos, ações, funções eclesiais do Espírito), a antropologia teológica, o aspecto eclesial (sentir com a Igreja e profetismo), as intuições sobre os sacramentos, a escatologia, o mistério do mal, o testemunho do mistério 
de Deus, a sensibilidade social, a defesa da mulher e, evidentemente, o tema da oração.

Na segunda etapa pós-conciliar, a partir de 1982 até a celebração do V Centenário de nascimento da Santa, vai sendo percebida a influência do novo contexto religioso e cultural do século XXI na investigação sobre Teresa de Jesus. Os estudos históricos e teológicos seguem sendo aprofundados. Surge um novo interesse pelo diálogo com as ciências modernas, a psicologia, a literatura e a mística comparada. A sensibilidade religiosa atual, que busca o diálogo intercultural e inter-religioso também deixará sua marca nas novas investigações. Segundo Ciro García, os estudos teresianos se inculturam (GARCIA, 2015, p. 480-481). As atas dos congressos em preparação ao V Centenário de nascimento de Santa Teresa, organizados em Ávila (CITeS-Universidad de la Mística) ilustram estes interesses. Observando apenas as atas do congresso dedicado ao livro Castelo Interior ou Moradas, é possível perceber a permanência e aprofundamento dos temas históricos, linguístico-literários e teológico-doutrinais (bíblicos, patrísticos, mística comparada, Trindade, cristofania, antropologia, oração, experiência de Deus, etc.); faz-se notar o diálogo com a psicologia da experiência mística, com autores contemporâneos, com a mística judaica, islâmica e do contexto africano; buscam-se interfaces com interesses contemporâneos, como a meditação mindfulness e a floricultura (cor, jardim e flores), e o interesse pedagógico que atualize a dimensão prática do livro (SANCHO FERMIN; CUARTAS LONDOÑO, 2014, p. 543-551). Não deixa de ter interesse constatar que, dos vinte e sete estudos constantes nestas atas, onze são de mulheres.

Tudo isto mostra como uma doutrina testemunhal (e martirial), cheia de humanidade, como a de Santa Teresa de Jesus, possui virtualidades insuspeitadas, pois cada tempo histórico lança sobre ela suas perguntas e sua luz e, ao mesmo tempo, busca dela extrair iluminação. Trata-se de um tesouro inesgotável, segredos de Deus na história, a encantar a vida e provocar a teologia.

\section{Conclusões}

Ao fim deste artigo, é possível traçar algumas conclusões.

1. Santa Teresa revela a interrelação entre teologia, santidade e humanidade. O doutorado teresiano coloca a teologia diante de uma mulher de Deus e humana, cuja doutrina não se separa da sua santidade e, esta, da sua humanidade. Ao contrário, há uma relação intrínseca entre elas. Teologia, santidade e humanidade traçam uma rede consistente e concedem aos escritos teresianos uma autoridade testemunhal. Sua obra - doutrinal, histórica ou poética - revela o perfil multifacetado da autora, que inclui presença crítica e ativa no contexto eclesial e sociopolítico, atinge realidades como 
os pobres de seu entorno, as estruturas da nobreza, os acontecimentos da Europa e das Américas; habilidade literária e capacidade de comunicação com os leitores; empatia que tende a construir comunidade; comunicação que tende a aprofundar amizade; interesse pelas ciências, pela saúde física e psíquica; bom humor; proximidade das artes e da beleza. Enfim, uma humanidade generosa, profética e empática.

2. Teresa de Ávila ajuda a rever a noção de Deus. Sua obra revela um Deus próximo, comprometido com a vida concreta e com o conviver; em Jesus Cristo, Humanidade sagrada, revelou-se amor efetivo e corpóreo, solidário com as mulheres, propiciador de justiça e paz. Assim sendo, a experiência de Deus é irradiadora de vida nova e libertação, coloca em marcha histórias pessoais e coletivas de salvação. O doutorado teresiano mostra como a teologia não pode ser separada desta experiência de fé que é, ao mesmo tempo, divina e humanizadora - nas palavras de Paulo VI, desta sabedoria das coisas divinas e das coisas humanas.

3. O doutorado teresiano significou a superação do impedimento do sexo e do não pertencimento à hierarquia eclesiástica para o doutorado e o reconhecimento do múnus magisterial da mulher na Igreja, não sem conflitos. A doutrina teresiana conheceu, ao longo dos séculos, um reconhecimento que pode ser mensurado pelo êxito editorial ininterrupto, em dezenas de línguas. A primeira publicação das obras completas de Teresa de Jesus deu-se em 1588, a apenas seis anos de sua morte. No entanto, a declaração oficial como Doutora da Igreja deu-se apenas após o Concílio Vaticano II, pelo Papa Paulo VI, em 1970. A Igreja precisou de séculos para vencer o impedimento do sexo para tal declaração. Isto significou, ao mesmo tempo, a alienação e a invisibilização das mulheres no estudo e do magistério teológico na Igreja, embora elas sempre tenham desempenhado papel de suma importância no aprofundamento e transmissão da fé. Por outro lado, o reconhecimento do doutorado teresiano (primeiro de outros reconhecimentos de mulheres doutoras) corrobora, de maneira oficial, o múnus magisterial da mulher na Igreja, fundado no Batismo, para a edificação e enriquecimento da Igreja e para a expansão do Reino de Deus na terra. Em outras palavras, a teologia afirma que necessita do labor teológico das mulheres. O caráter carismático e profético desta reorientação já traz em si um prenúncio de oposições, quer pela tradição patriarcal ainda presente nas instâncias eclesiais e mesmo na academia, quer pela inércia interessada - ambas claramente visibilizadas na trajetória histórica da Santa Doutora, como foi visto.

4. O doutorado teresiano contribuiu para o aprofundamento teológico. Fruto do sensus fidei que significou o Concílio Vaticano II, conectou com o sensus fidei do povo que o recebeu, aprofundou a tradição mais genuína da Igreja e provocou significativo crescimento, tanto dos estudos teresianos quanto dos estudos da mística, enquanto teologia e enquanto fonte 
de estudos teológicos sistemáticos. As celebrações do IV Centenário de morte, do V Centenário do nascimento e, recentemente, dos 50 anos do doutorado teresiano o revelam. Também o revelam as teses doutorais, estágios pós-doutorais, dissertações de mestrado, iniciações científicas e monografias sobre a mística em geral e sobre Santa Teresa, em particular, nas universidades e centros teológicos, muitos realizados por mulheres estudantes de teologia. A mulher "inquieta e andarilha" ainda inspira novas "saídas".

5. O itinerário de Santa Teresa nos mostra uma mulher excepcional que foi, ao mesmo tempo, admirada e perseguida, louvada e desqualificada, lida e censurada. A distância histórica revelou as razões, a genialidade e a fecundidade do testemunho de fé dessa figura gigante. Muito sofrimento escondido foi revelado nos estudos de sua obra e nas pesquisas históricas sobre ela. Fato que remete a maior humildade institucional em seus preconceitos com relação às mulheres na teologia.

6. Enfim, a Doutora da Igreja convida a uma teologia humanizadora, com novas dinâmicas antropológicas possibilitadas pela abertura a Deus - Humanidade sagrada -, autoconhecimento libertador, transformação interior e ética, encontro com Deus na criação e de tudo em Deus - "só Deus basta". Novas dinâmicas no interior da Igreja, com crescimento na consciência cristã de que todos são sujeitos, chamados à resposta de fé com ousadia e fidelidade criativa, segundo relações de respeito e reconhecimento das mulheres em seus escritos e palavras. Novas dinâmicas no mundo - para Santa Teresa, ele "está ardendo" (C 1,5), a exigir o compromisso de cada um, pois "não é tempo de tratar com Deus negócios de pouca importância" (C 1,5).

\section{Siglas}

$$
\begin{array}{ll}
\mathrm{C} & =\text { Caminho de Perfeição } \\
\mathrm{CE} & =\text { Camino de Perfección } \\
\mathrm{CIgC} & =\text { Catecismo da Igreja Católica } \\
\mathrm{Cta} . & =\text { Cartas } \\
\mathrm{DV} & =\text { Dei Verbum } \\
\mathrm{F} & =\text { Fundações } \\
\mathrm{GeE} & =\text { Gaudete et Exsultate } \\
\mathrm{LG} & =\text { Lumen Gentium } \\
\mathrm{M} & =\text { Castelo interior ou Moradas } \\
\mathrm{R} & =\text { Relações } \\
\mathrm{V} & =\text { Livro da Vida }
\end{array}
$$




\section{Referências}

ALVAREZ, T. Actualidad y razón teológica del doctorado de Santa Teresa. In: ALVAREZ, T. Estudios teresianos I. Burgos: Monte Carmelo, 1995. p. 683-701.

ALVAREZ, T. Santa Teresa y las mujeres en la Iglesia: Camino 3. In: ALVAREZ, T. Estudios Teresianos III. Burgos: Monte Carmelo, 1996. p. 491-504.

BANBRIDGE, M. M. Mujer/es. In: ALVAREZ, T. Diccionario de Santa Teresa de Jesús. Burgos: Monte Carmelo, 2000, p. 1010-1019.

CASTELLANO, J. Presencia de Santa Teresa en la teología y en la espiritualidad actua:. Balance y perspectivas. Teresianum, Roma, v. 33, n. 1-2, p. 181-232, 1982.

CATECISMO DA IGREJA CATÓLICA. 6 ed. Petrópolis: Vozes; São Paulo: Ave-Maria, Loyola, Paulinas, 1993.

COMPÊNDIO DO VATICANO II. Constituição dogmática Dei Verbum. 20.ed. Petrópolis: Vozes, 1989. p. 119-139.

COMPÊNDIO DO VATICANO II. Constituição dogmática Lumen Gentium. 20.ed. Petrópolis: Vozes, 1989. p. 37-117.

FRANCISCO, Papa. Exortação Apostólica Gaudete et Exsultate: sobre a chamada à santidade no mundo atual. São Paulo: Paulinas, 2018.

FRANCISCO, Papa. Mensagem por ocasião do quinto centenário do nascimento de Teresa de Ávila, 2014. Vaticano: 15 out. 2014. Disponível em: <http://www.vatican.va/content/francesco/ pt/messages/pont-messages/2014/documents/papa-francesco_20141015_messaggio-500-teresa-avila.html>. Acesso em: 05 jun. 2021.

GARCIA, C. Bollettino Bibliográfico Teresiano. Teresianum, Roma, v. 66, n. 1-2, p. 479-517, 2015.

HERRAIZ GARCIA, M. Oração, história de amizade. 2.ed. São Paulo: Carmelitanas/ Loyola, 2002.

PAULO VI, PP. Carta Apostólica Multiformis Sapientia Dei. Vaticano: 27 set. 1970a. Disponível em: $<$ https://www.vatican.va/content/paul-vi/es/apost_letters/documents/hf_p-vi_apl_19700927 _multiformis-sapientia.html>. Acesso em: 05 jun. 2021.

PAULO VI, PP. Proclamação de Santa Teresa de Jesus Doutora da Igreja. Vaticano: 27 set. 1970b. Disponível em: <https://www.vatican.va/content/paul-vi/pt/homilies/1970/documents/hf_ p-vi_hom_19700927.html>. Acesso em: 05 jun. 2021.

PEDROSA-PÁDUA, L. Santa Teresa de Jesus: Mística e humanização. São Paulo: Paulinas, 2015.

PEDROSA-PÁDUA, L. Vida e significado de Santa Teresa de Jesus. In: PEDROSA-PÁDUA, L.; CAMPOS, M.B. (Orgs.). Santa Teresa: Mística para o nosso tempo. Rio de Janeiro: PUC-Rio; São Paulo: Reflexão, 2011. p. 19-53.

PEDROSA-PÁDUA, L. Teresa de Ávila e a parábola do bicho-da-seda: Encantamento em prosa para um renascer em Cristo. Teoliterária, São Paulo, v. 9, n. 19, p. 239-251, 2019.

RAHNER, K. La experiencia personal de Dios más apremiante que nunca. Revista de Espiritualidad, Madrid, v. 29, n. 116/117, p. 310-312, Jul./Dec. 1970. 
SANCHO FERMIN, F.J.; CUARTAS LONDOÑO, R. (Dir.). Las Moradas del Castillo Interior de Santa Teresa de Jesús: Actas del IV Congreso Teresiano en preparación del V Centenario de su nacimiento (1515-2015). Burgos: Monte Carmelo; Ávila: Universidad de la Mística-CITeS, 2014.

SANCHO FERMIN, F.J.; CUARTAS LONDOÑO, R.; NAWOJOWSKI, J. (Dir.). Teresa de Jesús, patrimonio de la humanidade: Actas del Congreso Mundial Teresiano en el V Centenario de su nacimiento (1515-2015). Burgos: Monte Carmelo; Ávila: Universidad de la Mística-CITeS, 2016.

SCKILLEBEECKX, E. Profetas de la presencia viva de Dios. Revista de Espiritualidad, Madrid, v. 29, n. 116/117, p. 319-321, Jul./Dec. 1970.

SIMEON DE LA S. FAMILIA. Bibliografía del doctorado teresiano. Ephemerides Carmelitanae, Roma, v. 22, n. 2, p. 399-494, 1971.

TERESA D'ÁVILA, Santa. Caminho de Perfeição. In: TERESA D'ÁVILA, Santa. Obras Completas. São Paulo: Paulinas, 2018a. p. 425-610.

TERESA D’ÁVILA, Santa. Castelo Interior ou Moradas. In: TERESA D’ÁVILA, Santa. Obras Completas. São Paulo: Paulinas, 2018b. p. 611-812.

TERESA D'ÁVILA, Santa. Fundações (As). In: TERESA D'ÁVILA, Santa. Obras Completas. São Paulo: Paulinas, 2018c. p. 813-1049.

TERESA D’ÁVILA, Santa. Livro da Vida. In: TERESA D’ÁVILA, Santa. Obras Completas. São Paulo: Paulinas, 2018d. p. 43-424.

TERESA D'ÁVILA, Santa. Relações (As). In: TERESA D’ÁVILA, Santa. Obras Completas. São Paulo: Paulinas, 2018e. p. 1051-1131.

TERESA DE JESUS, Santa. Camino de Perfección. Códice de El Escorial. In: TERESA DE JESUS, Santa. Obras Completas. 4.ed. Madrid: EDE, 1994. p. 521-655.

TERESA DE JESUS, Santa. Cartas. In: TERESA DE JESUS, Santa. Obras Completas. São Paulo: Carmelitanas/Loyola, 1995a. p. 1031-1696.

TERESA DE JESUS, Santa. Relações. In: TERESA DE JESUS, Santa. Obras Completas. São Paulo: Carmelitanas/Loyola, 1995b. p. 773-839.

TERESA, Santa. Libro de la Vida. In: TERESA DE JESUS, Santa. Obras Completas. 10.ed. Burgos: Monte Carmelo, 1998. p. 3-414.

Artigo submetido em 20.06.2021 e aprovado em 29.10.2021.

Lúcia Pedrosa-Pádua é Doutora em Teologia pela PUC-Rio, com bolsa-sanduíche na Pontificia Universidad de Salamanca e Centro Internacional de Estudios Teresiano-Sanjuanistas de Ávila. Professora e pesquisadora do Departamento de Teologia da PUC-Rio. Prêmio Internacional Santa Teresa y el Diálogo Interreligioso. Orcid.org/0000-0003-0383-7677. E-mail: lpedrosa@puc-rio.br

Endereço: Departamento de Teologia - PUC-Rio

Rua Marquês de São Vicente 225

Prédio Leme, $11^{\circ}$ andar - Gávea

22451-900 Rio de Janeiro - RJ 